\title{
Diversity and role of plasmids in adaptation of bacteria inhabiting the Lubin copper mine in Poland, an environment rich in heavy metals
}

\section{Lukasz Dziewit ${ }^{1 *}$, Adam Pyzik ${ }^{1}$, Magdalena Szuplewska ${ }^{1}$, Renata Matlakowska ${ }^{2}$, Sebastian Mielnicki ${ }^{2}$, Daniel Wibberg ${ }^{3}$, Andreas Schlüter ${ }^{3}$, Alfred Pühler ${ }^{3}$ and Dariusz Bartosik ${ }^{1}$}

${ }^{1}$ Department of Bacterial Genetics, Institute of Microbiology, Faculty of Biology, University of Warsaw, Warsaw, Poland

${ }^{2}$ Laboratory of Environmental Pollution Analysis, Faculty of Biology, University of Warsaw, Warsaw, Poland

${ }^{3}$ Institute for Genome Research and Systems Biology, Center for Biotechnology (CeBiTec), Bielefeld University, Bielefeld, Germany

\section{Edited by:}

Malin Bomberg, VTT Technical

Research Centre of Finland, Finland

Reviewed by:

Angel Valverde, University of

Pretoria, South Africa

Miguel Angel Cevallos, Centro de

Ciencias Genomicas-Universidad

Nacional Autónoma de México,

Mexico

*Correspondence:

Lukasz Dziewit, Department of Bacterial Genetics, Institute of

Microbiology, Faculty of Biology,

University of Warsaw, Miecznikowa

1. Warsaw, 02-096, Poland

e-mail: Idziewit@biol.uw.edu.pl
The Lubin underground mine, is one of three mining divisions in the Lubin-Glogow Copper District in Lower Silesia province (Poland). It is the source of polymetallic ore that is rich in copper, silver and several heavy metals. Black shale is also significantly enriched in fossil organic matter in the form of long-chain hydrocarbons, polycyclic aromatic hydrocarbons, organic acids, esters, thiophenes and metalloporphyrins. Biological analyses have revealed that this environment is inhabited by extremophilic bacteria and fungi. Kupfershiefer black shale and samples of water, bottom and mineral sediments from the underground (below $600 \mathrm{~m}$ ) Lubin mine were taken and 20 bacterial strains were isolated and characterized. All exhibited multi-resistant and hypertolerant phenotypes to heavy metals. We analyzed the plasmidome of these strains in order to evaluate the diversity and role of mobile DNA in adaptation to the harsh conditions of the mine environment. Experimental and bioinformatic analyses of 11 extrachromosomal replicons were performed. Three plasmids, including a broad-host-range replicon containing a Tn3 family transposon, carried genes conferring resistance to arsenic, cadmium, cobalt, mercury and zinc. Functional analysis revealed that the resistance modules exhibit host specificity, i.e., they may increase or decrease tolerance to toxic ions depending on the host strain. The other identified replicons showed diverse features. Among them we identified a catabolic plasmid encoding enzymes involved in the utilization of histidine and vanillate, a putative plasmid-like prophage carrying genes responsible for NAD biosynthesis, and two repABC-type plasmids containing virulence-associated genes. These findings provide an unique molecular insight into the pool of extrachromosomal replicons and highlight their role in the biology and adaptation of extremophilic bacteria inhabiting terrestrial deep subsurface.

Keywords: plasmid, Tn3 transposon, underground copper mine, terrestrial deep subsurface, extremophilic bacteria, heavy metal

\section{INTRODUCTION}

Bacterial plasmids, as extrachromosomal mobile genetic elements, are components of many microbial genomes. They have modular structures, since it is possible to dissect them into several functional genetic modules. The plasmid backbone is composed of a set of conserved modules, coding for replication, stability and conjugal transfer functions, which are crucial for plasmid maintenance and spread. Many plasmids also carry accessory genes determining various phenotypes, e.g., antibiotics resistance and utilization of toxic compounds. Such genetic information is not crucial for host viability, but it may play an important role in the adaptation of bacteria to various environments, including terrestrial deep subsurface habitats (Sobecky and Coombs, 2009; Heuer and Smalla, 2012; Nojiri, 2013).
It was shown that one of the most frequently found phenotypic modules carried by bacterial plasmids are heavy metal resistance genes (Silver, 1996). Moreover, metal resistance genes are often co-localized on plasmids together with antibiotic resistance genes, and they are frequently present within transposable and integrative mobile elements (Rahube et al., 2014). Such plasmidencoded heavy metal resistance systems are usually related to chromosomally-encoded determinants found in other bacteria, which exemplifies the naturally occurring gene flow (Silver, 1996).

Horizontal gene transfer is a major mechanism contributing to bacterial diversification and adaptation, and plasmids are the main players in this process (Heuer and Smalla, 2012). Many plasmids are self-transmissible or mobilizable replicons, which can be transferred from one host to another, together with various 
"passenger" genes (often embedded within transposons), which can be useful under particular selection pressures (Tamminen et al., 2012). This phenomenon is extremely profitable for bacteria and, in effect, speeds up the process of evolution. To explain the link between environmental conditions and the diversity of bacterial plasmids a complex molecular analyses or, so called, metaanalyses of plasmidomes of bacteria inhabiting various (especially unique) extremophilic environments are needed (Dziewit and Bartosik, 2014).

The Lubin underground mine, is one of the three mining divisions in the Lubin-Glogow Copper District located in the Lower Silesia province (Poland). This mine is the source of polymetallic ore that is highly rich in copper (10 wt.\%) and silver (100 mg kg-1) (Oszczepalski, 1999). Besides these two elements $\mathrm{As}, \mathrm{Co}, \mathrm{V}, \mathrm{Ni}, \mathrm{Pb}$, and $\mathrm{Zn}$ at high concentrations were also detected (Speczik, 1994, 1995; Oszczepalski, 1999). All mentioned elements occur in the form of sulfides and sulphosalts [e.g., bornite $\left(\mathrm{Cu}_{5} \mathrm{FeS}_{4}\right)$, chalcopyrite $\left(\mathrm{CuFeS}_{2}\right)$ ], gersdorffite (NiAsS), nickeline (NiAs), cobaltite (CoAsS), minerals belonging to the tennantite-tetrahedrite series $\left[(\mathrm{Cu}, \mathrm{Fe}){ }_{12} \mathrm{As}_{4} \mathrm{~S}_{13}-(\mathrm{Cu}\right.$, $\mathrm{Fe})_{12} \mathrm{Sb}_{4} \mathrm{~S}_{13}$, sphalerite $(\mathrm{ZnS})$ and galena $\left.(\mathrm{PbS})\right]$. A characteristic feature of these deposits is a neutral or slightly alkaline $\mathrm{pH}$ reaching 8.5. Black shale is also significantly enriched in fossil organic matter (up to $30 \%$ ) in the form of long-chain saturated and unsaturated hydrocarbons, polycyclic aromatic hydrocarbons, organic acids and esters, as well as thiophenes and metalloporphyrins (Sklodowska et al., 2005; Matlakowska and Sklodowska, 2011). Biological analyses have revealed that this hostile environment is inhabited by endemic and extremophilic microorganisms, including bacteria and fungi (Matlakowska and Sklodowska, 2009; Rajpert et al., 2013).

In our previous work we analyzed several strains of the genus Pseudomonas originating from the Lubin copper mine (Szuplewska et al., 2014). Using a trap plasmid strategy to capture functional transposable elements, we identified several insertion sequences and transposons (autonomous and non-autonomous), some of which carry predicted genetic modules of adaptive value (Szuplewska et al., 2014). In this study we extended our investigation of the mobilome of bacteria inhabiting this deep underground environment. We isolated and analyzed the plasmids of strains representing various taxonomic groups, focusing on replicons conferring heavy metal resistance. Such plasmids (and their bacterial hosts) may be exploited in industrial processes, e.g. bioleaching of metals or biormediation. Moreover, the naturally occurring plasmids are good candidates for the construction of vectors for the genetic manipulations of biotechnologically important bacteria. However, this requires an in-depth understanding of the plasmid biology.

\section{MATERIALS AND METHODS \\ BACTERIAL STRAINS, PLASMIDS AND CULTURE CONDITIONS}

The bacterial strains and plasmids used in this study are listed in Table S1. The strains were grown in LB (Luria-Bertani) medium (Sambrook and Russell, 2001) at $37^{\circ} \mathrm{C}$ (E. coli) or 22 and $30^{\circ} \mathrm{C}$ (other strains). Where necessary, the medium was supplemented with sucrose $(10 \%)$ and the antibiotics, kanamycin (50-1000 $\mu \mathrm{g} / \mathrm{ml})$ and rifampicin $(50 \mu \mathrm{g} / \mathrm{ml})$.

\section{SAMPLE COLLECTION AND BACTERIAL ISOLATION}

Samples of black shale, mineral sediment, bottom sediment and water, collected from various sites within the Lubin underground copper mine (below $600 \mathrm{~m}$ ), were placed in sterile plastic tubes and held at $4^{\circ} \mathrm{C}$ until they were processed in the laboratory.

To isolate bacterial strains, samples of solid matter $(10 \mathrm{~g})$ were resuspended in $20 \mathrm{ml}$ of $0.85 \% \mathrm{NaCl}(\mathrm{pH} 7.0)$ and shaken at $22^{\circ} \mathrm{C}$ for $2 \mathrm{~h}$. Then a series of dilutions were prepared in saline solution and plated onto solid LB medium. Diluted water samples were plated directly onto LB medium. The plates were incubated at $22^{\circ} \mathrm{C}$ for 2 weeks. All operations were carried out aseptically.

\section{AMPLIFICATION AND SEQUENCING OF 16S rRNA GENES}

A colony PCR method was used for the amplification of 165 rRNA gene fragments (Gathogo et al., 2003). PCR was performed with the primers $27 \mathrm{f}$ and $1492 \mathrm{r}$ (Lane, 1991). The amplified 16S rDNA fragments were used as templates for DNA sequencing with an ABI Prism 377 automatic sequencer (Applied Biosystems).

\section{PHYSIOLOGICAL ANALYSES OF THE BACTERIAL STRAINS}

The temperature, $\mathrm{pH}$ and salinity tolerance of bacteria were analyzed by monitoring changes in the optical density of cultures (in comparison with non-inoculated controls) according to the procedures described previously (Dziewit et al., 2013). For the motility assay LB soft agar plates containing $0.3,0.35$, or $0.4 \%(\mathrm{w} / \mathrm{v})$ agar were inoculated with the bacteria using a sterile toothpick and incubated at $30^{\circ} \mathrm{C}$ for $48 \mathrm{~h}$.

The minimum inhibitory concentrations (MICs) of selected heavy metal ions were established. For this purpose, analytical grade salts $\left(3 \mathrm{CdSO}_{4} \times 8 \mathrm{H}_{2} 0 ; \mathrm{CoSO}_{4} \times 7 \mathrm{H}_{2} 0 ; \mathrm{CuSO}_{4} ; \mathrm{HgCl}_{2} ;\right.$ $\mathrm{K}_{2} \mathrm{Cr}_{2} \mathrm{O}_{7} ; \mathrm{NaAsO}_{2} ; \mathrm{Na}_{2} \mathrm{HAsO}_{4} \times 7 \mathrm{H}_{2} \mathrm{O} ; \mathrm{NiCl}_{2} \times 6 \mathrm{H}_{2} 0 ; \mathrm{NaO}_{3} \mathrm{~V}$; $\mathrm{ZnSO}_{4} \times 7 \mathrm{H}_{2} 0$ ) were used in an assay procedure described previously (Dziewit et al., 2013). Isolates that grew in the presence of at least the following metal ion concentrations were considered resistant: (i) $20 \mathrm{mM} \mathrm{V}^{5+}$, (ii) $10 \mathrm{mM} \mathrm{As}^{5+}$, (iii) $1 \mathrm{mM} \mathrm{As}^{3+}$, $\mathrm{Cd}^{2+}, \mathrm{Co}^{2+}, \mathrm{Cu}^{2+}, \mathrm{Ni}^{2+}, \mathrm{Zn}^{2+}$, or $\mathrm{Cr}^{6+}$, and (iv) $0.1 \mathrm{mM} \mathrm{Hg}^{2+}$ (Nieto et al., 1987; Abou-Shanab et al., 2007).

The ability to produce siderophores was examined by application of the modified chrome azurol S (CAS) agar plate method (Schwyn and Neilands, 1987). The plates were incubated at $30^{\circ} \mathrm{C}$ for $72 \mathrm{~h}$ in the dark and the formation of halos around colonies was recorded.

\section{DNA MANIPULATIONS, PLASMID ISOLATION AND INTRODUCTION OF PLASMID DNA INTO BACTERIAL CELLS}

Bacterial plasmids were isolated according to the method of Birnboim and Doly (Birnboim and Doly, 1979), and when required, the DNA was further purified by CsCl-ethidium bromide gradient centrifugation (Sambrook and Russell, 2001). Plasmid DNA was also isolated using a Plasmid Mini Kit (A\&A Biotechnology), Plasmid Miniprep Kit Gene Matrix $\left(\mathrm{EUR}_{\mathrm{x}}\right)$ and GeneJET Plasmid Miniprep Kit (Thermo SCIENTIFIC). The visualization of mega-sized replicons was achieved by in-gel lysis and DNA electrophoresis according to a method described previously (Wheatcroft et al., 1990). The common DNA manipulations were performed as described earlier (Sambrook and Russell, 2001). PCR was performed in a Mastercycler (Eppendorf) using 
Taq DNA polymerase (Qiagen; with supplied buffer), dNTP mixture and appropriate primer pairs (Table S1). Triparental mating was performed as described previously (Bartosik et al., 2001).

\section{PLASMID DNA SEQUENCING AND ASSEMBLY}

The complete nucleotide sequences of plasmids pLM16A1, pLM20P1-5, pLM8P1, and pLM12P1 were determined in the Laboratory of DNA Sequencing and Oligonucleotide Synthesis (oligo.pl) at the Institute of Biochemistry and Biophysics, Polish Academy of Sciences, Warsaw, Poland. Plasmids pLM19O1, pLM19O2, and pLM21S1 were sequenced at the Center for Biotechnology (CeBiTec), Bielefeld University, Germany. Highthroughput sequencing of the MID-tagged shotgun plasmidlibraries was performed using a Genome Sequencer FLX system (Roche/454 Life Sciences). The GS de novo assembler software (Roche) was applied for the sequence assemblies. Primer walking and polymerase chain reaction (PCR) were used to close physical gaps between assembled contigs. The amplified DNA fragments were sequenced using an ABI3730xl DNA Analyzer (Applied Biosystems).

\section{IDENTIFICATION OF ACTIVE TRANSPOSABLE ELEMENTS (TEs)}

The identification of functional TEs using trap plasmid pMAT1 was performed as described previously (Szuplewska and Bartosik, 2009; Dziewit et al., 2012).

\section{PHAGE INDUCTION}

Phage of Sinorhizobium sp. LM21 was induced using mitomycin $\mathrm{C}$ as described previously (Dziewit et al., 2014b).

\section{FUNCTIONAL ANALYSIS OF THE HEAVY METAL RESISTANCE MODULES}

A restriction fragment or PCR-amplified DNA regions containing the resistance genes of plasmids pLM20P1 (ARS module), pLM20P2 (CZC) and pLM16A1 (MER) were cloned into the broad-host-range mobilizable vector pBBR1MCS-2, to produce plasmids pBBR-CZCLM20, pBBR-ARSLM20 and pBBRMERLM16 (Table S1). For comparison, two resistance cassettes of functional transposable elements identified within Pseudomonas spp. strains LM7 and LM14 (Szuplewska et al., 2014) were also included. Those were (i) the CZC module of insertion sequence ISPpu12a (3372 bp, ISL3 family), encoding a predicted $\mathrm{CzcD}$ protein, possibly involved in resistance to $\mathrm{Co}^{2+}, \mathrm{Zn}^{2+}$, and $\mathrm{Cd}^{2+}$, and (ii) MER, a mercury resistance operon of the Tn3 family transposon Tn5563a (6253 bp), containing three genes-merP, merT (encoding mercury transporters) and merR (encoding a transcription regulator). To analyze these modules we used two previously obtained derivatives of the pBBR1MCS-2-based broad host range mobilizable trap plasmid pMAT1, namely pMAT-ISPPU12A and pMATTN5563A, carrying inserted ISPpu12a and Tn5563a, respectively (Table S1) (Szuplewska et al., 2014).

All five plasmids containing predicted resistance modules were introduced into 13 bacterial strains (LM5, LM6, LM7, LM8, LM10, LM12, LM14, LM15, LM16, LM19, LM21, LM24, and LM25), representing Alpha-, Beta- and Gammaproteobacteria. As controls, two laboratory strains, Agrobacterium tumefaciens LBA288 (type strain of Alphaproteobacteria) and E. coli TG1 (Gammaproteobacteria), were also selected as the hosts for the plasmids. The resistance phenotypes of the obtained transconjugants (or transformants) were then tested by determining the minimum inhibitory concentrations (MICs) for $\mathrm{As}^{3+}, \mathrm{As}^{5+}$, $\mathrm{Cd}^{2+}, \mathrm{Co}^{2+}, \mathrm{Zn}^{2+}$, and $\mathrm{Hg}^{2+}$ salts in liquid culture and the obtained values were compared with those of the wild-type strains.

\section{PLASMID HOST RANGE TESTING}

To analyze the host range of plasmids pLM16A1, pLM20P1, and pLM20P2, three mobilizable shuttle plasmids (pABW-LM20P1, pABW-LM20P2, and pABW-LM16A1) were constructed (Table S1), containing the replication modules of the resistance plasmids and an E. coli-specific pMB1 (ColE1-type) replication system [vector pABW1 (Bartosik et al., 1997)]. The obtained plasmids were introduced via conjugation into 14 strains (LM5, LM6, LM7, LM8, LM10, LM12, LM14, LM15, LM16, LM19, LM21, LM24, LM25, and LBA288). The plasmids were also introduced via transformation into E. coli BR825 (Gammaproteobacteria). Since the ColE1-type replication system is not functional in any of the recipient strains (E. coli BR825 carries a mutation within the DNA polymerase I gene that blocks ColE1-type replication), all functions required for replication of the shuttle plasmids in the tested hosts were provided by the REP modules of pLM20P1, pLM20P2 or pLM16A1.

\section{BIOINFORMATIC ANALYSES}

Plasmid nucleotide sequences were analyzed using Clone Manager Professional, version 9.0 (Sci-Ed software), Artemis (Carver et al., 2008) and GenDB 2.0 (Meyer et al., 2003). Similarity searches were performed using the BLAST programs (Altschul et al., 1997) and the PRIAM tool (Claudel-Renard et al., 2003). Putative tRNA genes were identified with the tRNAscanSE program (Lowe and Eddy, 1997). Comparative genomic analyses were performed with the application of the ACT: the Artemis comparison tool (Carver et al., 2008). The reference data set for the computational prediction of metabolic pathways was obtained from the MetaCyc database (Caspi et al., 2014). Phylogenetic analysis was performed using MEGA6 (Tamura et al., 2013), applying the neighbor-joining algorithm with 1000 bootstrap replicates. The initial alignment obtained with ClustalW (Chenna et al., 2003) was manually refined. For the analysis 100 homologs (best BLAST hits) of proteins ArsB, ArsC, $\mathrm{CzcD}$, and MerA retrived from the UniProt database (Apweiler et al., 2004) were used.

\section{NUCLEOTIDE SEQUENCE ACCESSION NUMBERS}

The sequences of $16 \mathrm{~S}$ rRNA genes determined in this study have been deposited in GenBank (NCBI), with the following accession numbers: KF769960 (strain LM16), KF769961 (LM17), KF769962 (LM18), KF769963 (LM19), KF769964 (LM20), KF769965 (LM21), KF769966 (LM22), KF769967 (LM23), KF769968 (LM24), KF769970 (LM26).

The plasmid sequences determined in this study have been deposited in GenBank (NCBI), with the following accession numbers: KM659090 (plasmid pLM16A1), KM659091 (pLM19O1), KM659092 (pLM19O2), KM659093 (pLM20P1), KM659094 (pLM20P2), KM659095 (pLM20P3), KM659096 (pLM20P4), KM659097 (pLM20P5), KM659098 (pLM21S1), KM659088 (pLM8P1) and KM659089 (pLM12P1). 


\section{RESULTS \\ IDENTIFICATION AND CHARACTERIZATION OF BACTERIA ISOLATED FROM THE LUBIN COPPER MINE}

In this study we analyzed 20 bacterial strains isolated from various samples collected from the terrestrial deep subsurface environment, namely Lubin copper mine: (i) black shale (strains LM5, LM6, LM7, LM8, LM17, LM18, LM20, LM23, LM25, LM26); (ii) water (LM10, LM12, LM24); (iii) mineral sediment (LM11, LM14, LM21) and (iv) bottom sediment (LM15, LM16, LM19, LM22). Ten of the strains (belonging to the genus Pseudomonas - LM5, LM6, LM7, LM8, LM10, LM11, LM12, LM14, LM15, and LM25) were identified and subjected to preliminary characterization in previous studies (Matlakowska and Sklodowska, 2009; Szuplewska et al., 2014). However, detailed physiological or genomic analyses have not been done for these Pseudomonas strains so far. The remaining 10 strains were classified on the basis of comparative analyses of the obtained 16S rDNA sequences applying the RDP (Ribosomal Database Project) (Cole et al., 2009) and GenBank (NCBI) databases. This analysis revealed that the majority of the uncharacterized bacterial isolates represented different classes of Proteobacteria: (i) 5 strains of Alphaproteobacteria-Brevundimonas sp. LM17 and LM18, Ochrobactrum sp. LM19, Paracoccus yeei LM20 and Sinorhizobium sp. LM21; (ii) 1 of Betaproteobacteria-Achromobacter sp. LM16; and (iii) 2 of Gammaproteobacteria-Psychrobacter sp. LM26 and Stenotrophomonas sp. LM24. The two remaining strains (LM22 and LM23) were identified as members of the genus Sphingobacterium, belonging to the Bacteroidetes phylum. Based on their 16S rDNA sequences three of the analyzed strains (LM7, LM10, and LM20) could be identified as Pseudomonas mendocina LM7, Pseudomonas aeruginosa LM10 and Paracoccus yeei LM20.

Preliminary physiological characterization of all identified bacterial strains revealed that 13 could grow at temperatures ranging from 15 to $37^{\circ} \mathrm{C}$, or even $42^{\circ} \mathrm{C}$ (this growth pattern is typical for mesophilic bacteria), while 7 strains were psychrotrophs, able to grow at temperatures between 4 and $37^{\circ} \mathrm{C}$ (the optimum temperature for all strains was either 21 or $30^{\circ} \mathrm{C}$ ) (Table S2). All strains grew in $\mathrm{LB}$ medium at $\mathrm{pH}$ values close to 7 , which is characteristic for neutrophilic bacteria. Three strains (LM7, LM16, and LM19) displayed properties of facultative alkaliphiles, since they could tolerate $\mathrm{pH}$ values of up to 11 (Table S2) (Slonczewski et al., 2009). Salinity tolerance testing revealed that the majority (18) of the strains were non-halophilic bacteria, while LM14 and LM26 could tolerate a higher $\mathrm{NaCl}$ concentration (6\%); thus they were classified as halotolerant (Table S2) (Larson, 1986). The motility assay revealed that 15 of the tested strains were motile (Table S2). Moreover, application of the universal chrome azurol $\mathrm{S}$ (CAS) agar plate assay indicated that 16 of the analyzed strains produced iron-chelating siderophores (Table S2).

\section{GENERAL CHARACTERIZATION OF THE PLASMIDOME OF THE IDENTIFIED BACTERIA}

Plasmid screening of all bacterial isolates revealed the presence of 12 circular replicons ranging in size from approx. 1.7 to $120 \mathrm{~kb}$. Six strains contained plasmids: Achromobacter sp. LM16, Ochrobactrum sp. LM19, P. yeei LM20, Pseudomonas sp.
LM8, Pseudomonas sp. LM12 and Sinorhizobium sp. LM21. The nucleotide sequences of all but one of these replicons [pLM8P2 of Pseudomonas sp. LM8 was described in our previous study (Szuplewska et al., 2014)], were obtained and analyzed. This revealed that the plasmids contained from 2 to 150 predicted genes and their average GC content varied between 53.5 and $67.3 \%$. The plasmids carried as many as 22 types of predicted genetic modules, involved in various functions. The results of the overall characterization of the plasmids are shown in Table 1. A summary of genes identified in each plasmid, including their position, the size of the putative encoded proteins and their closest homologs, is presented in Tables S3-S7.

For each plasmid, a conserved backbone, composed of the maintenance and conjugal transfer modules (including modules responsible for mobilization for conjugal transfer) was distinguished. In silico analysis of the plasmid-encoded accessory modules showed plasmids containing genes of direct adaptive value: (i) heavy metal resistance plasmids (pLM16A1, pLM20P1 and pLM20P2), (ii) a catabolic plasmid (pLM20P5), and other replicons, including a (iii) plasmid-like prophage (pLM21S1), (iv) putative virulence plasmids (pLM19O1 and pLM19O2) and (v) cryptic plasmids (pLM20P3, pLM20P4, pLM8P1 and pLM12P1). In our analyses we mainly focused on heavy metal resistance plasmids.

\section{GENOMICS OF HEAVY METAL RESISTANCE PLASMIDS}

Three plasmids were found to carry predicted genetic modules involved in heavy metal resistance: pLM20P1 and pLM20P2 of $P$. yeei LM20, and pLM16A1 of Achromobacter sp. LM16 (Figure 1, Tables S3, S4). The average GC content of the nucleotide sequences of the plasmids is $62.7,63.4$, and $64.2 \%$ (Table 1), respectively, which is lower than the mean values determined for the total DNA of the bacteria belonging to Achromobacter and Paracoccus genus-66.4\% (mean result for 11 genomes) and $67.3 \%$ (mean result for 27 genomes), respectively.

Two plasmids of $P$. yeei LM20 are small replicons (6 and $6.2 \mathrm{~kb}$, respectively) encoding replication initiation proteins with homology to related proteins of plasmids occurring in several carotenoid-producing strains of Paracoccus spp. (Maj et al., 2013). Plasmid pLM20P1 carries three arsenic-tolerance genes (ARS module; pLM20P1_p3-pLM20P1_p5) encoding arsenate reductase (ArsC), an efflux pump (ArsB) and an ArsR family transcriptional repressor. The small cytoplasmatic arsenate reductase ArsC is responsible for the conversion of arsenate $\left(\mathrm{As}^{5+}\right)$ into arsenite $\left(\mathrm{As}^{3+}\right)$, while the membrane protein ArsB is an effective chemiosmotic efflux system mediating the removal of $\mathrm{As}^{3+}$ from the cell (Silver and Phung Le, 2005a,b). Interestingly, the ARS module of pLM20P1 shares $80 \%$ nucleotide sequence identity with the appropriate gene cluster of chromid pAMI5 of Paracoccus aminophilus JCM 7686 (Dziewit et al., 2014a). The second plasmid, pLM20P2 carries a CZC module, encoding a MerR family transcriptional regulator (pLM20P2_p3) and a predicted CzcD cation transport membrane protein (pLM20P2_p4) [member of the cation diffusion facilitator (CDF) protein family], which mediates cobalt $\left(\mathrm{Co}^{2+}\right)$, zinc $\left(\mathrm{Zn}^{2+}\right)$ and cadmium $\left(\mathrm{Cd}^{2+}\right)$ resistance (Anton et al., 2004). This DNA region shares 
Table 1 | General features of plasmids of bacteria from the Lubin mine.

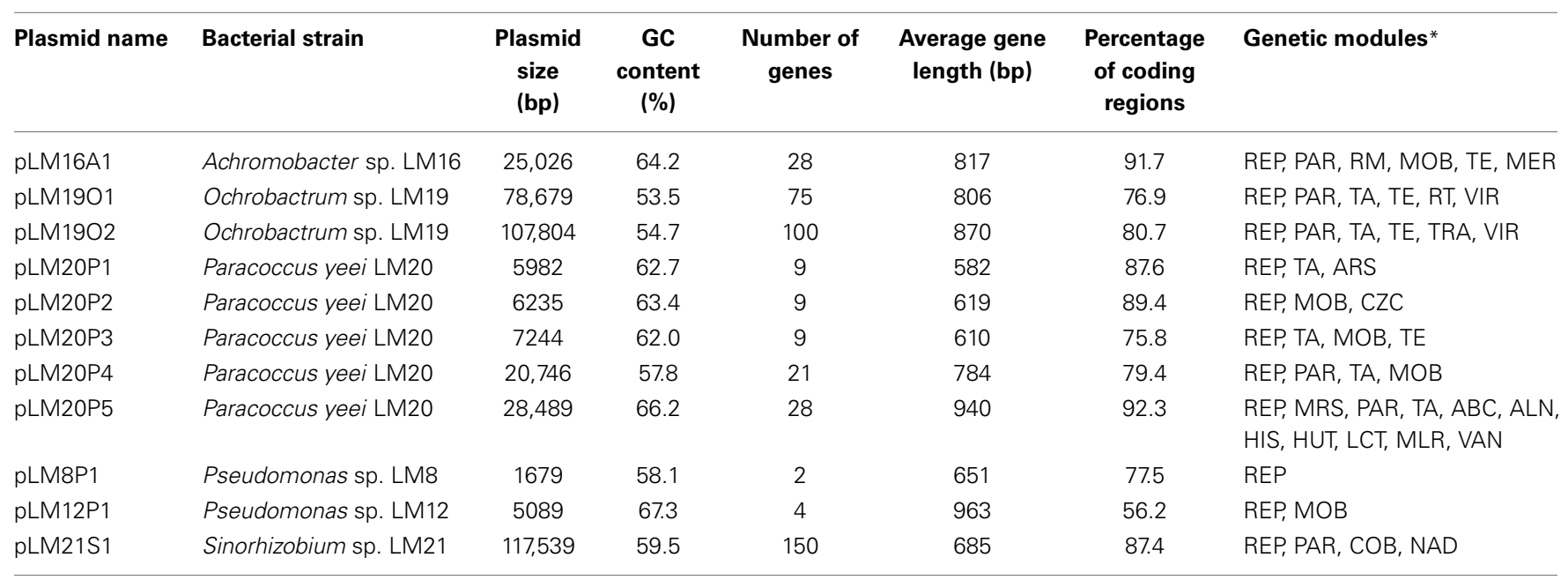

${ }^{*} A B C, A B C$-type transporter system; ALN, allantoate amidohydrolase; ARS, arsenic resistance module; COB, cobalamine biosynthesis module; CZC, cobalt, zinc,

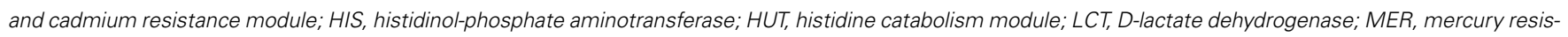

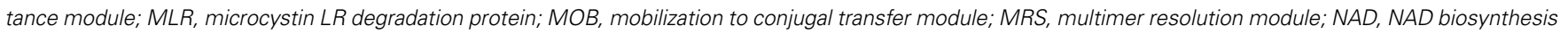

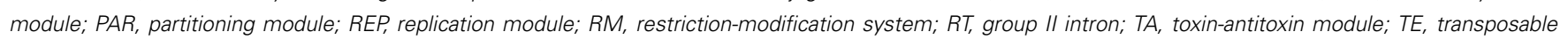
element; TRA, conjugal transfer module; VAN, vanillate utilization module; VIR, virulence factors.

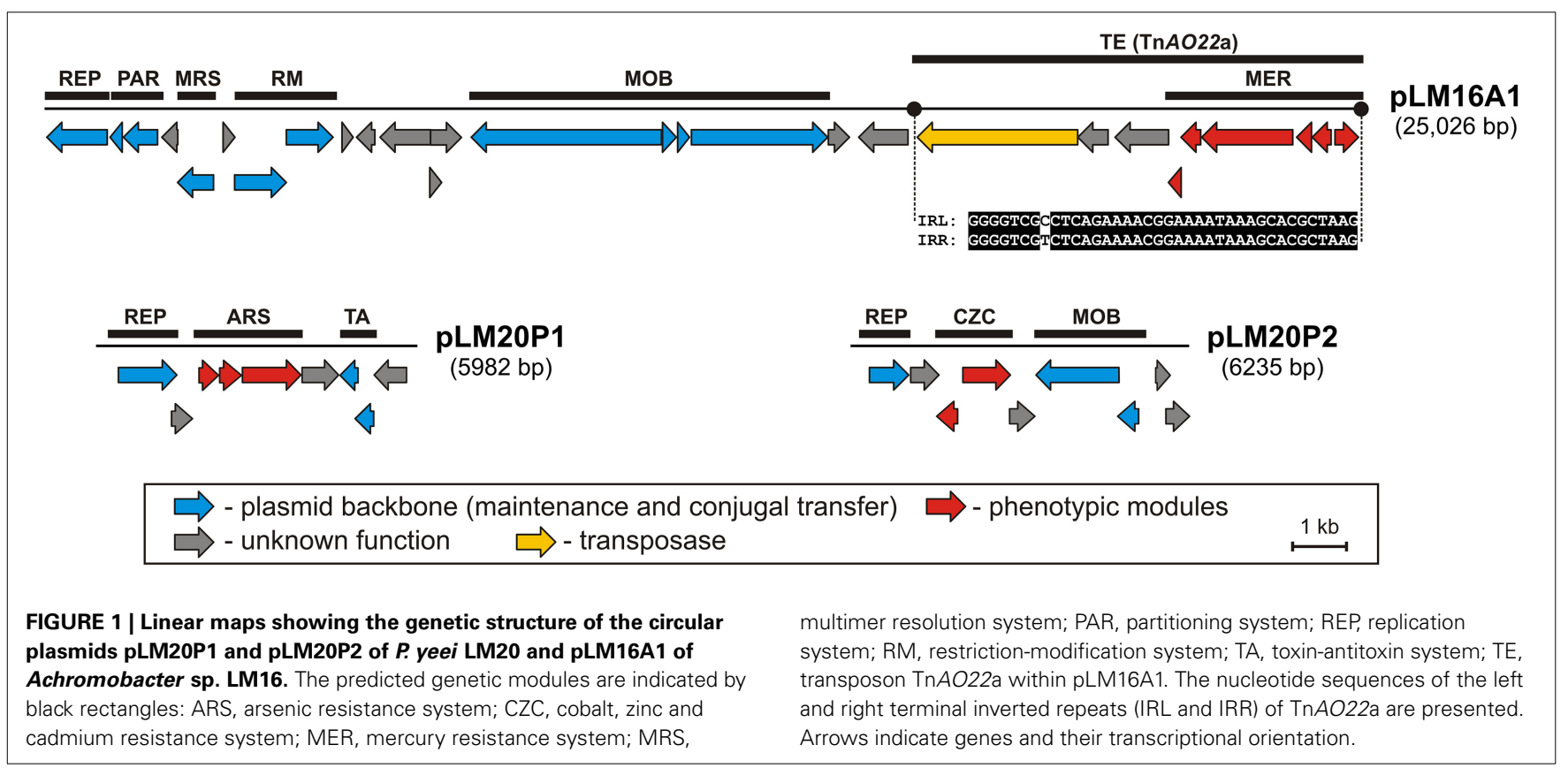

high level (69\%) of nucleotide sequence identity with appropriate CZC module of a large, extrachromosomal, alphaproteobacterial replicon-NT26_p1 of Rhizobium sp. NT-26 (Andres et al., 2013).

The third plasmid, pLM16A1 of Achromobacter sp. LM16 $(25 \mathrm{~kb})$, has a mosaic structure. More than half of the plasmid genome shares at least $84 \%$ nucleotide sequence identity with transposon TNCP23 of plasmid pKLC102, coexisting as an autonomous replicon and a genomic island in Pseudomonas aeruginosa (Klockgether et al., 2004; Bonnin et al., 2013).
Plasmid pLM16A1 contains the following modules: (i) a replication system, encoding a RepA protein (pLM16A1_p1); (ii) a partitioning system (pLM16A1_p2-pLM16A1_p3); (iii) a putative multimer resolution system (pLM16A1_p5); (iv) a type II restriction-modification system (pLM16A1_p7-pLM16A1_p8), whose restriction endonuclease (predicted recognition sequence GCCGGC) shares 68\% amino acid sequence identity with R.NgoMIV from Neisseria gonorrhoeae MS11 (Stein et al., 1992); (v) a MOB module; and (vi) a mercury resistance module (MER; pLM16A1_p23-pLM16A1_p28) (Figure 1). 
The MER module consists of 6 genes encoding proteins responsible for the enzymatic conversion of $\mathrm{Hg}^{2+}$ ions to the less toxic form $\mathrm{Hg}^{0}$ (metallic mercury). The key enzyme is the mercuric reductase (MerA), which reduces $\mathrm{Hg}^{2+}$ to $\mathrm{Hg}^{0}$. The other five MER-encoded proteins include two mercury ion transporters (MerT and MerP), two transcriptional regulators (MerR and MerD) and an accessory membrane protein (MerE) of unknown function. The pLM16A1 MER module is embedded within a transposon (TnAO22a; $8240 \mathrm{bp}$ ), which is an isoform (99\% nucleotide sequence identity) of $\operatorname{Tn} A O 22$, previously identified in Achromobacter sp. AO22 (Ng et al., 2009). Using a positiveselection trap vector (pMAT1) to identify functional transposable elements, we demonstrated that $\operatorname{Tn} A O 22 \mathrm{a}$ is capable of transposition and therefore may contribute to the dissemination of mercury resistance.

We also performed a phylogenetic analysis of the heavy metal resistance modules of plasmids pLM20P1, pLM20P2, and pLM16A1. For the analysis ArsB, ArsC, CzcD, and MerA proteins were used. We found that the close homologs of ArsB and ArcC proteins are encoded mostly within the genomes of Alphaproteobacteria, including several strains of Paracoccus spp. (Figures S1, S2). Interestingly, proteins related to $\mathrm{CzcD}$ are encoded not only by Alphaproteobacteria, but also by members of the phylum Thaumarchaeota (Archaea), which may suggest the inter-domain gene transfer (Figure S3). The fourth analyzed protein, MerA, has close relatives encoded within the genomes of various gram-negative (Beta- and Gammaproteobacteria), as well as gram-positive bacteria (Mycobacterium spp. and Bacilli) (Figure S4).

\section{HOST RANGE AND FUNCTIONAL ANALYSES OF HEAVY METAL RESISTANCE PLASMIDS}

Heavy metal tolerance of wild-type strains was determined. Ten heavy metal ions were examined: $\mathrm{As}^{3+}, \mathrm{As}^{5+}, \mathrm{Cd}^{2+}, \mathrm{Co}^{2+}$, $\mathrm{Cr}^{6+}, \mathrm{Cu}^{2+}, \mathrm{Hg}^{2+}, \mathrm{Ni}^{2+}, \mathrm{V}^{5+}$, and $\mathrm{Zn}^{2+}$. All tested strains showed resistance to at least 4 of the 10 tested ions. In total we found 146 (out of 200 tested) resistance phenotypes. One strain, $P$. aeruginosa LM10, exhibited resistance to all of the tested ions, while Pseudomonas sp. LM15 and LM25, Achromobacter sp. LM16, Ochrobactrum sp. LM19, Sinorhizobium sp. LM21, Sphingobacterium sp. LM22 and Stenotrophomonas sp. LM24 showed resistance to 9 of them (Table 2). All strains tolerated high levels of arsenate (60-1200 mM), nickel (1-6 mM) and copper $(2-10 \mathrm{mM})$, while 19 isolates were resistant to arsenite (1$25 \mathrm{mM}$ ). In contrast, only 8 isolates showed (low level) resistance to chromium (VI) (Table 2).

Then, the functionality of the resistance modules (from plasmids pLM20P1, pLM20P2, and pLM16A1, and transposable elements ISPpu12a and Tn5563a) was tested in various hosts and the obtained values were compared with those of the wild-type strains (Figure 2). This analysis revealed that the introduction of the plasmids to the recipient strains resulted in a significant increase (at least 2-fold) in the MICs in 30 (20\%) of the transconjugants, while decreases in the MICs of at least 2-fold were observed in 22 (14.7\%) (Figure 2, Table S8).

The putative CZC module of plasmid pLM20P2 (CZC-LM20) was active, but produced a resistance phenotype in only a limited number of strains: Pseudomonas spp. LM5, LM6 and LM8 (increased resistance to $\mathrm{Cd}^{2+}, \mathrm{Co}^{2+}, \mathrm{Zn}^{2+}$; MIC increases of at

Table 2 | Heavy metals resistance of bacteria isolated from the Lubin mine.

\begin{tabular}{|c|c|c|c|c|c|c|c|c|c|c|}
\hline & \multicolumn{10}{|c|}{ Heavy metals resistance (MICs) (mM)* } \\
\hline & $\mathrm{As}^{3+}$ & $\mathrm{As}^{5+}$ & $\mathrm{Cd}^{2+}$ & $\mathrm{Co}^{2+}$ & $\mathrm{Cr}^{6+}$ & $\mathrm{Cu}^{2+}$ & $\mathrm{Hg}^{2+}$ & $\mathrm{Ni}^{2+}$ & $\mathbf{V}^{5+}$ & $\mathrm{Zn}^{2+}$ \\
\hline Achromobacter sp. LM16 & 25 & 1200 & 7 & 1.5 & 0.8 & 10 & 0.3 & 6 & 200 & 10 \\
\hline Brevundimonas sp. LM17 & 2 & 250 & 0.1 & 0.6 & 0.2 & 5 & 0.01 & 3 & 1 & 2 \\
\hline Brevundimonas sp. LM18 & 2 & 250 & 0.1 & 0.7 & 0.4 & 4 & 0.02 & 2 & 20 & 2 \\
\hline Ochrobactrum sp. LM19 & 9 & 1000 & 2 & 1 & 2 & 8 & 0.02 & 4 & 200 & 10 \\
\hline Paracoccus yeei LM20 & 6 & 400 & 1 & 1.5 & 0.1 & 3 & 0.08 & 2 & 5 & 1 \\
\hline Pseudomonas sp. LM5 & 1 & 400 & 0.1 & 0.5 & 0.6 & 3 & 0.06 & 2 & 75 & 0.6 \\
\hline Pseudomonas sp. LM6 & 0.6 & 75 & 0.1 & 0.5 & 0.2 & 3 & 0.2 & 3 & 15 & 0.6 \\
\hline Pseudomonas mendocina LM7 & 15 & 500 & 0.6 & 0.4 & 2 & 5 & 0.2 & 3 & 150 & 0.9 \\
\hline Pseudomonas sp. LM8 & 7 & 250 & 0.1 & 0.5 & 0.3 & 3 & 0.2 & 3 & 15 & 0.4 \\
\hline Pseudomonas aeruginosa LM10 & 4 & 250 & 6 & 2 & 2 & 9 & 0.2 & 3 & 30 & 15 \\
\hline Pseudomonas sp. LM11 & 3 & 500 & 0.1 & 0.4 & 0.6 & 2 & 0.2 & 3 & 75 & 0.3 \\
\hline Pseudomonas sp. LM12 & 2 & 400 & 0.2 & 0.6 & 0.3 & 4 & 0.2 & 3 & 75 & 0.8 \\
\hline Pseudomonas sp. LM14 & 15 & 250 & 0.1 & 1.5 & 0.4 & 9 & 0.1 & 4 & 250 & 6 \\
\hline Pseudomonas sp. LM15 & 7 & 500 & 1 & 4 & 3 & 8 & 0.01 & 6 & 40 & 6 \\
\hline Pseudomonas sp. LM25 & 6 & 500 & 4 & 3 & 2 & 8 & 0.01 & 6 & 30 & 5 \\
\hline Psychrobacter sp. LM26 & 4 & 200 & 0.1 & 0.8 & 2 & 5 & 0.02 & 1 & 100 & 2 \\
\hline Sinorhizobium sp. LM21 & 5 & 200 & 2 & 1.5 & 1 & 5 & 0.02 & 4 & 50 & 3 \\
\hline Sphingobacterium sp. LM22 & 3 & 250 & 2 & 2 & 0.3 & 7 & 0.2 & 5 & 100 & 9 \\
\hline Sphingobacterium sp. LM23 & 2 & 60 & 1 & 0.3 & 0.2 & 4 & 0.02 & 2 & 30 & 2 \\
\hline Stenotrophomonas sp. LM24 & 4 & 350 & 2 & 0.9 & 2 & 8 & 0.1 & 5 & 60 & 10 \\
\hline
\end{tabular}

${ }^{*}$ MICs considered to represent the heavy metal resistance phenotype were shown in bold. 


\begin{tabular}{|c|c|c|c|c|c|}
\hline \multirow[b]{3}{*}{ tested strain } & \multicolumn{2}{|c|}{$\begin{array}{c}\text { plasmid-encoded } \\
\text { modules }\end{array}$} & \multicolumn{3}{|c|}{$\begin{array}{c}\text { TE-encoded } \\
\text { modules }\end{array}$} \\
\hline & $\begin{array}{l}\text { CZC- } \\
\text { LM20 } \\
\end{array}$ & $\begin{array}{l}\text { ARS- } \\
\text { LM20 } \\
\end{array}$ & $\begin{array}{l}\text { MER- } \\
\text { LM16 }\end{array}$ & $\begin{array}{c}\text { CZC- } \\
\text { IS }\end{array}$ & $\begin{array}{l}\text { MER- } \\
\text { TN }\end{array}$ \\
\hline & 䓠 & 志㕝 & $\begin{array}{l}\text { Ñ } \\
\text { ర্ }\end{array}$ & 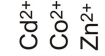 & $\begin{array}{l}\stackrel{+}{0} \\
\text { O⿱一土 }\end{array}$ \\
\hline Pseudomonas sp. LM5 & & $\mathbf{\square} \square$ & $\mathbf{\square}$ & $\square \square \square$ & $\square$ \\
\hline Pseudomonas sp. LM6 & & $\mathbf{\square}$ & $\square$ & $\square \square \square$ & $\square$ \\
\hline P. mendocina LM7 & $\square \square \square$ & $\square \square$ & $\mathbf{\square}$ & $\square \square \square$ & $\square$ \\
\hline Pseudomonas sp. LM8 & & $\square \square$ & $\square$ & $\square \square \square$ & $\square$ \\
\hline P. aeruginosa LM10 & $\square \square \square$ & $\square \square$ & $\square$ & $\square \square \square$ & $\square$ \\
\hline Pseudomonas sp. LM12 & $\square \square \square$ & $\square \square$ & $\mathbf{\square}$ & $\square \square \square$ & $\square$ \\
\hline Pseudomonas sp. LM14 & $\square \square \square$ & $\square \square$ & I & $\square \square \square$ & $\square$ \\
\hline Pseudomonas sp. LM15 & $\square \square \square$ & $\square \square$ & I & $\square \square \square$ & $\mathbf{\square}$ \\
\hline Pseudomonas sp. LM25 & $\square \square \square$ & $\square \square$ & $\mathbf{\square}$ & $\square \square \square$ & $\mathbf{\square}$ \\
\hline Achromobacter sp.LM16 & $\square \square \square$ & $\square \square$ & $\square$ & $\square \square \square$ & $\square$ \\
\hline Ochrobactrum sp. LM19 & $\square \square \square$ & $\square \square$ & & $\square \square \square$ & $\square$ \\
\hline Sinorhizobium sp. LM21 & $\square \square \square$ & $\square \square$ & 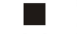 & $\square \square \square$ & $\square$ \\
\hline Stenotrophomonas sp. LM24 & $\square \square \square$ & $\square \square$ & & $\square \square \square$ & $\square$ \\
\hline A. tumefaciens LBA288 & $\mathbf{\square} \square$ & $\mathbf{\square} \square$ & $\mathbf{\square}$ & $\square \square \square$ & $\square$ \\
\hline E. coli TG1 & $\square \square \square$ & $\square \square$ & $\square$ & $\square \square \square$ & $\square$ \\
\hline \multicolumn{6}{|c|}{\begin{tabular}{|l|} 
\\
$\square$ - at least 2-fold increased tolerance $\quad \square$ - lack of significant changes \\
\end{tabular}} \\
\hline \multicolumn{6}{|c|}{$\begin{array}{l}\text { FIGURE } 2 \text { I Influence of the CZC, ARS, and MER modules on the heavy } \\
\text { metal tolerance of bacterial strains inhabiting the Lubin copper mine, } \\
\text { plus the controls } \boldsymbol{A} \text {. tumefaciens and } \boldsymbol{E} \text {. coli. CZC-LM20, cobalt, zinc and } \\
\text { cadmium resistance module of plasmid pLM20P2; ARS-LM20, arsenic } \\
\text { resistance module of pLM2OP1; MER-LM16, mercury resistance module of } \\
\text { plasmid pLM16A1; CZC-IS, cobalt, zinc and cadmium resistance module of } \\
\text { ISPpu12a; MER-TN, mercury resistance module of plasmid Tn5563a. }\end{array}$} \\
\hline
\end{tabular}

least 3-fold) and A. tumefaciens LBA288 (elevated resistance to $\mathrm{Cd}^{2+}$ and $\mathrm{Zn}^{2+}$; MIC increases of 2- and 2.5-fold, respectively). In contrast, the CZC-IS module of ISPpu12a did not confer resistance to $\mathrm{Cd}^{2+}, \mathrm{Co}^{2+}$, or $\mathrm{Zn}^{2+}$ in any of the tested transconjugant strains and hence probably was inactive. In a few cases, presence of the CZC-LM20 and CZC-IS modules resulted in a decrease in the MIC values (Figure 2, Table S8).

The arsenic resistance module of pLM20P1 (ARS-LM20) was tested for its ability to increase the tolerance of bacteria to arsenite and arsenate ions. Only 5 strains carrying pBBR-ARSLM20 (Pseudomonas spp. LM5, LM6, LM12, Sinorhizobium sp. LM21 and A. tumefaciens LBA288) exhibited at least 2-fold higher resistance to arsenite or arsenate compared to their parental wild-type strains (Figure 2, Table S8).

The MER modules analyzed in this study originated from plasmid pLM16A1 (MER-LM16 module) and transposon Tn5563a (MER-TN module) and were predicted to confer resistance to mercury ions. As mentioned above, the MER-LM16 module carries a complete set of genes commonly found in other well defined mercury resistance operons (Silver and Phung Le, 2005b), while MER-TN is a partial module, carrying only three genes (merRTP). Introduction of the MER-TN module resulted in a significant increase in the MIC for $\mathrm{Hg}^{2+}$ in only two strains, while the MICs of six other strains were at least 2-fold decreased. In contrast, presence of the MER-LM16 module increased tolerance to $\mathrm{Hg}^{2+}$ in $11(73.3 \%)$ strains. Interestingly, introduction of plasmid pBBR-MERLM16 into two strains (LM6 and LM16) originally exhibiting high levels of resistance to mercury, resulted in an unexpected decrease in tolerance (Figure 2, Table S8).

We also tested the host range of plasmids pLM20P1, pLM20P2, and pLM16A1. The replication system of pLM16A1 was functional in all tested strains, which indicates its broad host range. In contrast, plasmids replication modules of pLM20P1 and pLM20P2 were found to have a relatively narrow host range, limited to a few strains of Alphaproteobacteria. Both plasmids were able to replicate in A. tumefaciens LBA288, and the latter one could also replicate in Sinorhizobium sp. LM21.

\section{DIVERSITY AND GENOMICS OF OTHER PLASMIDS OF BACTERIA ISOLATED FROM THE LUBIN MINE}

Amongst identified replicons we found one catabolic plasmid, pLM20P5 of $P$. yeei LM20. The plasmid carries 28 predicted genes (Figure 3A). Of these, 12 encode enzymes directly linked with: (i) purine metabolism, (ii) pyruvate metabolism, (iii) vanillate utilization and (iv) amino acid and peptide transport and metabolism (Figure 3A, Table S3). Two of the pLM20P5-encoded phenotypic modules are of particular interest. One, responsible for the utilization of vanillate (an important intermediate in the lignin degradation process), is composed of three genes encoding vanillate $O$-demethylase [VanA and VanB subunits; (EC 1.14.13.82)] and a predicted LysR family transcriptional regulator (VanR). The formaldehyde-producing monooxygenase-type vanillate $O$-demethylase $\operatorname{Van} A B$ is crucial for the utilization of vanillate by its demethylation to protocatechuate (Figure 3A), which can then be degraded to central metabolism intermediates using the meta or ortho cleavage pathways (Masai et al., 2007; Chen et al., 2012). The second distinguished module (HUT) is involved in histidine utilization. It is composed of 7 genes encoding histidine ammonia lyase (HutH, EC 4.3.1.3), urocanase (HutU, EC 4.2.1.49), imidazolone propionate amidohydrolase (HutI, EC 3.5.2.7), formiminoglutamate deiminase (HutF, EC 3.5.3.13), formylglutamate amidohydrolase (HutG, EC 3.5.1.68), plus a histidine utilization repressor (HutR) and a HutD-family protein. The final products of this utilization pathway are Lglutamate and formate (Figure 3A) (Bender, 2012).

Another plasmid, pLM21S1 of Sinorhizobium sp. LM21, was found to carry numerous phage-related genes, encoding proteins required for DNA packaging, capsid and tail assembly, and cell lysis. This predicted plasmid-like prophage lacks an integrase gene, which suggests that it is not able to integrate into chromosomal DNA. Interestingly, pLM21S1 carries a RepC-like replication system, commonly found within large alphaproteobacterial plasmids (Cevallos et al., 2008). To check whether pLM21S1 is an active phage, we treated cells of Sinorhizobium sp. LM21 with mitomycin C, a classical inducer of lambdoid prophages. This approach did not cause phage induction, although it resulted in the induction of another indigenous prophage residing in the bacterial genome (Dziewit et al., 2014b). We speculate that pLM21S1 may be an inactive prophage, or alternatively it may require specific, as yet unidentified, environmental factors for induction.

Plasmid/phage pLM21S1 carries 147 putative genes and 3 tRNA-encoding sequences (Table S5). In total 83 of its genes are conserved in the genome of a related phage, RHEph10 of Rhizobium etli CFN42 (Santamaria et al., 2014) (Figure 3B). 


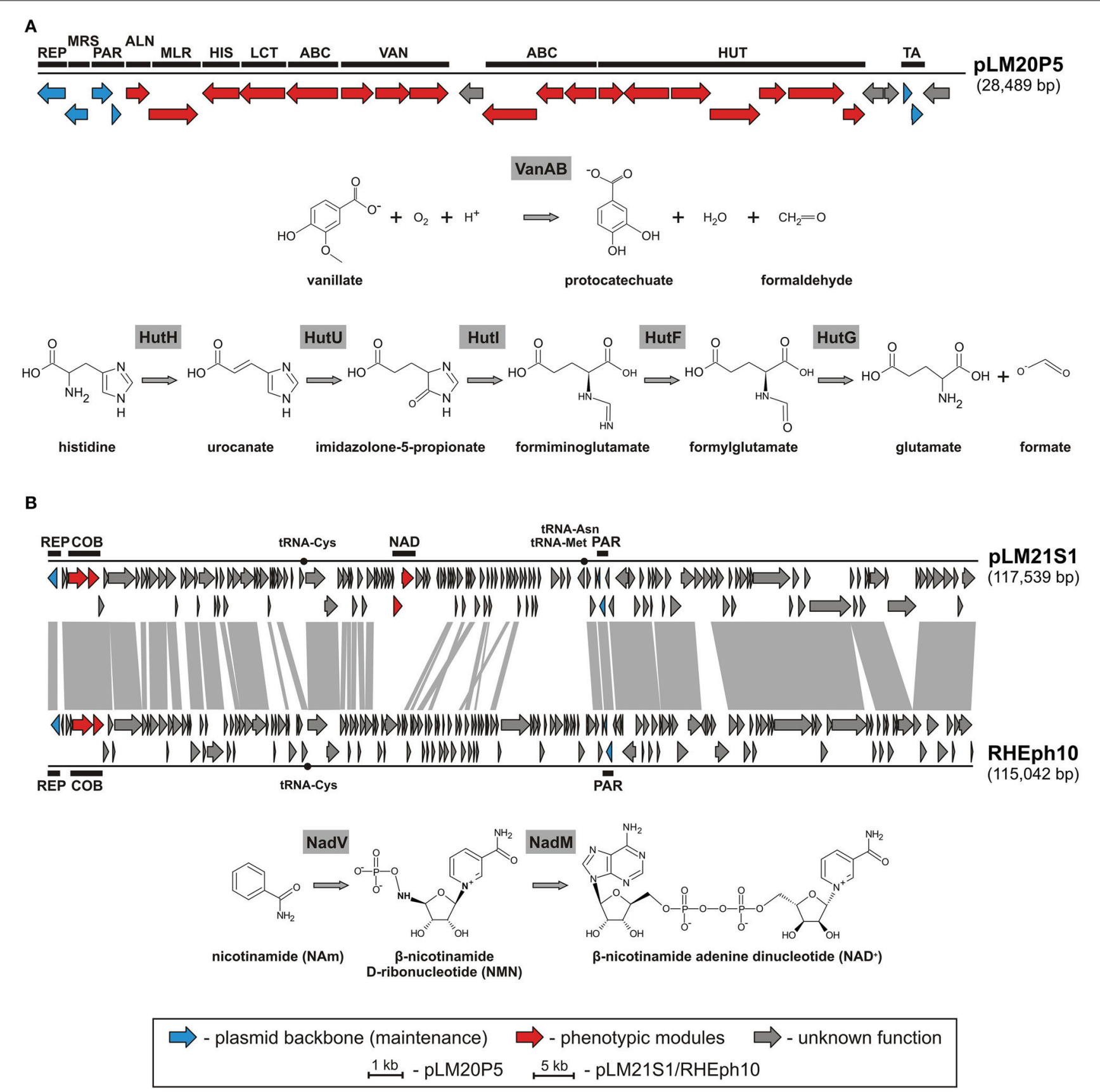

FIGURE 3 | Linear map showing the genetic structure of the circular plasmid pLM20P5 of $P$. yeei LM20 and schematic pathways for vanillate and histidine utilization (A), and linear map showing the genetic structures of the circular plasmid-like prophage pLM21S1 of Sinorhizobium sp. LM21 and Rhizobium phage RHEph10, and a schematic pathway for NAD biosynthesis (B). The predicted genetic modules are indicated by black rectangles: $A B C, A B C$-type transporter system; ALN, allantoate amidohydrolase; $\mathrm{COB}$, part of a cobalamine biosynthesis module; HIS, histidinol-phosphate aminotransferase; HUT, histidine utilization system; LCT, D-lactate dehydrogenase; MLR, microcystin LR degradation protein; MRS, multimer resolution system; NAD, NAD ${ }^{+}$ biosynthesis module; PAR, partitioning system; REP, replication system; TA, toxin-antitoxin system; VAN, vanillate utilization system. Arrows indicate genes and their transcriptional orientation. The tRNA-encoding sequences are marked by black dots. The gray-shaded area connects genes of plasmid pLM21S1 and phage RHEph10 that encode homologous proteins.
These two replicons carry homologous replication and partitioning systems, as well as putative genetic modules for cobalamine biosynthesis (cobTS) (Figure 3B). The CobT and CobS proteins form a complex, which together with an additional subunit, CobN (not encoded by the prophages) catalyzes cobalt incorporation into the corrin ring during the biosynthesis of coenzyme B12 (Debussche et al., 1992). Interestingly, pLM21S1 carries also genes involved in nicotinamide adenine 
dinucleotide (NAD) biosynthesis, which are not present in RHEph10. Of these, pLM21S1_p57 encodes a bifunctional nicotinamide mononucleotide adenylyltransferase/ADP-ribose pyrophosphatase (NadM, EC 2.7.7.1), while pLM21S1_p58 encodes nicotinamide phosphoribosyltransferase (NadV, EC 2.4.2.12). NadV catalyzes the transformation of nicotinamide (NAm) to $\beta$-nicotinamide ribonucleotide (NMN), which is then converted to NAD by the NadM enzyme (Figure 3B) (Martin et al., 2001). It has been suggested that the nadV-nadM module is not only responsible for NAD biosynthesis, but also for overall recycling of endogenous nicotinamide, which may be generated by the hydrolysis of NAD (Gerdes et al., 2006).

Next two replicons identified in the course of this study originated from Ochrobactrum sp. LM19. The plasmids pLM19O1 and pLM19O2 contain repABC modules (replication and partitioning functions) and carry 75 and 100 genes, respectively (Figure S5, Table S6). The bioinformatic analyses revealed that both replicons encode several virulence-associated proteins, including: (i) outer membrane autotransporter barrel domain-containing proteins of the type $\mathrm{V}$ secretion system, (ii) three invasion-associated locus $\mathrm{B}$ (IalB-like) proteins, whose homologs determine the erythrocyteinvasive phenotype of Bartonella bacilliformis (Coleman and Minnick, 2001), (iii) a YadA-like autotransporter adhesin of the non-fimbrial adhesins family, whose representatives are responsible for adhesion in infected tissues and protection against lysis (Hoiczyk et al., 2000), and (iv) an ATP-binding ABC-type transporter $(\mathrm{HlyB})$ and hemolysin $\mathrm{D}(\mathrm{HlyD})$ of the hemolysin A type I secretion system (Fath and Kolter, 1993) (Figure S5, Table S6).

The remaining four plasmids (pLM20P3 and pLM20P4 of P. yeei LM20, pLM8P1 of Pseudomonas sp. LM8 and pLM12P1 of Pseudomonas sp. LM12) identified in bacteria from the Lubin mine were designated as cryptic replicons, since they lack accessory modules (Tables S3, S7).

\section{DISCUSSION}

In this study we analyzed the plasmid content of 20 bacterial strains (representing eight genera of three classes of Proteobacteria and one genus of the Bacteroidetes phylum) isolated from the Lubin underground copper mine. The plasmidome of these strains comprised 12 replicons, whose genetic structure was revealed. We demonstrated the diversity of the plasmids and defined their adaptive value, focusing on heavy metal resistance, since these toxic elements are major contaminants of the Lubin copper mine environment influencing indigenous microoganisms.

The black shale horizon is exposed to the activity of oxygen, water, and microorganisms. These factors cause the chemical and biological weathering of the rock and strongly influences the geochemical cycles of heavy metals, as well as organic carbon, which results in further redistribution of the elements within the environment (Matlakowska et al., 2010, 2012; Matlakowska and Sklodowska, 2011). The geochemical examination of environmental samples of water and bottom sediment used in presented study confirmed the presence of heavy metals. For example, the concentrations of $\mathrm{Cu}, \mathrm{Pb}, \mathrm{Zn}$, As and $\mathrm{Ni}$ in sample of bottom sediment originated from underground pond were $6839 \mathrm{mg}$ $\mathrm{kg}^{-1}, 1128 \mathrm{mg} \mathrm{kg}^{-1}, 115 \mathrm{mg} \mathrm{kg}^{-1}, 110 \mathrm{mg} \mathrm{kg}^{-1}$ and $14 \mathrm{mg} \mathrm{kg}^{-1}$, respectively. Similarly, the mineral sediment taken from the surface of black shale contained copper at concentration $721 \mathrm{mg}$ $\mathrm{kg}^{-1}$.

High concentrations of heavy metals act as a specific selection pressure permitting the survival of only well adapted indigenous strains expressing multi-resistant and hypertolerant phenotypes. Our analysis confirmed that all the strains analyzed in this work exhibited such characteristics. The majority of them were resistant to high levels of copper, arsenic and nickel, which correlates with the composition of Kupferschiefer black shale [35000 $\mathrm{mg} \mathrm{kg}^{-1}$ for $\mathrm{Cu}, 398 \mathrm{mg} \mathrm{kg}^{-1}$ for As, $479 \mathrm{mg} \mathrm{kg}^{-1}$ for Ni (Matlakowska et al., 2012)]. We showed that some of the resistance phenotypes were confirmed by the mobile genetic elements.

Among the mobile genetic elements identified in the analyzed bacteria we found three plasmids (pLM16A1, pLM20P1, pLM20P2) and three transposable elements [TnAO22a, Tn5563a, ISPpu12a] that mediate resistance to arsenate, arsenite, cadmium, zinc, cobalt, and mercury. In-depth analyses demonstrated that the resistance phenotypes conferred by the particular elements are highly dependent on the host strain. Surprisingly, these results revealed that acquisition of a predicted resistance module is not always beneficial for the host, and may paradoxically lead to increased sensitivity. We speculate that this phenomenon may be the result of an unfavorable influence of the introduced genetic module on the overall homeostasis of the cell, e.g., by altering intracellular ion concentrations. All of the analyzed resistance modules encode influx/efflux pumps that are likely to have a relaxed substrate specificity [e.g., ArsB recognizes and functions with antimony, as well as arsenite (Silver and Phung Le, 2005a,b)], which may significantly influence ion fluxes.

An interesting example of a resistance module leading to increased sensitivity is the MER module of Tn3 family transposon Tn5563a [deletion derivative of Tn5044 of Xanthomonas campestris; (Kholodii et al., 2000)]. Transposon Tn5563a lacks merA (which is present in Tn5044), but it carries merP and merT genes encoding transporters responsible for the uptake of toxic mercuric ions. In six of the tested strains, the acquisition of this genetic module resulted in significant decreases in their MICs, which is probably the result of an increased intracellular concentration of toxic ions plus the inability of the strains to inactivate $\mathrm{Hg}^{2+}$ caused by the lack of MerA mercuric reductase. In contrast, increased tolerance was observed in two Pseudomonas spp. strains, possibly due to the presence of a chromosomal copy of the merA gene. Therefore it seems that the phenotypes determined by this module depend on the genetic background of the host strain.

The analyzed resistance modules are present on mobile genetic elements, so they may be readily transferred to other bacteria. We found that the replication system of the mobilizable plasmid pLM16A1 (containing MER) is functional in a broad range of hosts, which makes this replicon ideal for the horizontal dissemination of the mercury resistance phenotype. Moreover, the MER module of pLM16A1 (determining resistance in the great majority of tested strains) is located within an active Tn3 family transposon ( $\mathrm{Tn} A O 22 \mathrm{a})$, which enables its spread among different replicons co-residing in a single cell. 
The host range of the tested plasmids correlates with the results of phylogenetic analyses, which showed that the close homologs of ArsB, ArcC, and $\mathrm{CzcD}$ proteins (whose genes are located within narrow host range plasmids, pLM20P1 and pLM20P2) are encoded mostly within the genomes of Alphaproteobacteria, while MerA protein (encoded by the broad host range plasmid pLM16A1) is conserved among various gram-negative and gram-positive bacteria. Interestingly, it was also found that the homologs of the MER module are frequently colocalized with antibiotic resistance genes in various plasmids of Gammaproteobacteria [e.g., pACM1 (Preston et al., 2014), pHCM1 (Parkhill et al., 2001), pKOX_R1 (Huang et al., 2013)]. Those findings reflect the pivotal role of broad host range replicons in the dissemination of various resistance genes.

In the course of this study other replicons which may contribute to adaptation of their bacterial hosts to harsh environmental conditions of the Lubin mine were also identified. Amongst them, there was a catabolic replicon pLM20P5 of $P$. yeei LM20. It carries genetic modules, enabling the utilization of histidine and vanillate. These substrates can be used as alternative sources of carbon, nitrogen and energy. Since there is a limited amount of easily degradable carbon sources in the Lubin mine, it is likely that acquisition of catabolic plasmids such as pLM20P5 may be beneficial to the host.

An intriguing finding was also the identification of an unusual plasmid-like prophage element in Sinorhizobium sp. LM21. The replicon pLM21S1 has features typical of both, plasmids (replication and stable maintenance modules) and phages (complete set of proteins necessary for the phage "life cycle"). Plasmid pLM21S1 is related to the phage RHEph10, which is able to infect various Rhizbium etli strains (Santamaria et al., 2014). Accordingly, both replicons may be considered as the archetypes of a novel group of plasmid-like prophages. Interestingly, pLM21S1 carries the nadV-nadM genes responsible for NAD biosynthesis. The introduction of such genes into bacteria that neither possess the NAD de novo biosynthesis pathway, nor the NAD salvage pathway (e.g., Haemophilus influenzae), may transform them into "NAD-independent" strains, able to synthesize NAD from nicotinamide (Martin et al., 2001). We postulate that the presence of pLM21S1 may be beneficial to the host because NAD production is likely to improve the overall fitness of the bacterium, since NAD (and its derivative, NADP) is the most important coenzyme in cellular redox reactions (Martin et al., 2001).

Current knowledge concerning the direction, frequency and range of DNA transfer among microorganisms living in extreme environments, and especially deep terrestrial habitats, is sparse. We believe that the approach followed in the present study, linking geochemical data with physiological characterization of bacteria and detailed analyses of their plasmidome, may considerably increase our understanding of the influence of mobile DNA and horizontal gene transfer on the biology of extremophilic bacteria.

\section{ACKNOWLEDGMENT}

This work was supported by the National Science Centre, Poland [grant number N N303 579238].

\section{SUPPLEMENTARY MATERIALS}

The Supplementary Material for this article can be found online at: http://www.frontiersin.org/journal/10.3389/fmicb. 2015.00152/abstract

Figure S1 | Phylogenetic tree of the ArsB proteins homologous to ArsB efflux pomp encoded within pLM20P1. The analysis was based on 100 sequences retrieved from the UniProt database. The unrooted tree was constructed using the neighbor-joining algorithm and statistical support for the internal nodes was determined by 1000 bootstrap replicates. Values of $\geq 50 \%$ are shown. UniProt accession numbers of the protein sequences used for the phylogenetic analysis are given in parentheses. The underlined accession numbers indicate Paracoccus proteins.

Figure S2 | Phylogenetic tree of the ArsC proteins homologous to ArsC arsenate reductase encoded within pLM20P1. The analysis was based on 100 sequences retrieved from the UniProt database. The unrooted tree was constructed using the neighbor-joining algorithm and statistical support for the internal nodes was determined by 1000 bootstrap replicates. Values of $\geq 50 \%$ are shown. UniProt accession numbers of the protein sequences used for the phylogenetic analysis are given in parentheses. The underlined accession numbers indicate Paracoccus proteins.

Figure S3 | Phylogenetic tree of the CzcD proteins homologous to CzcD cation transport membrane protein encoded within pLM20P2. The analysis was based on 100 sequences retrieved from the UniProt database. The unrooted tree was constructed using the neighbor-joining algorithm and statistical support for the internal nodes was determined by 1000 bootstrap replicates. Values of $\geq 50 \%$ are shown. UniProt accession numbers of the protein sequences used for the phylogenetic analysis are given in parentheses. The underlined accession numbers indicate Paracoccus proteins.

Figure S4 | Phylogenetic tree of the MerA proteins homologous to MerA mercuric reductase encoded within PLM16A1. The analysis was based on 100 sequences retrieved from the UniProt database. The unrooted tree was constructed using the neighbor-joining algorithm and statistical support for the internal nodes was determined by 1000 bootstrap replicates. Values of $\geq 50 \%$ are shown. UniProt accession numbers of the protein sequences used for the phylogenetic analysis are given in parentheses. The underlined accession numbers indicate Achromobacter proteins.

Figure S5 | Linear map showing the genetic structure of the circular plasmids pLM1901 and pLM1902 of Ochrobactrum sp. LM19. The predicted genetic modules are indicated by black rectangles: PAR, partitioning system; REP, replication system; RT, group II intron; TA, toxin-antitoxin system; TE, transposable element; TRA, conjugal transfer system; VIR, virulence module. Arrows indicate genes and their transcriptional orientation. The gray-shaded area indicates the inversion region within pLM1901.

\section{REFERENCES}

Abou-Shanab, R. A., Van Berkum, P., and Angle, J. S. (2007). Heavy metal resistance and genotypic analysis of metal resistance genes in grampositive and gram-negative bacteria present in $\mathrm{Ni}$-rich serpentine soil and in the rhizosphere of Alyssum murale. Chemosphere 68, 360-367. doi: 10.1016/j.chemosphere.2006.12.051

Altschul, S. F., Madden, T. L., Schaffer, A. A., Zhang, J., Zhang, Z., Miller, W., et al. (1997). Gapped BLAST and PSI-BLAST: a new generation of protein database search programs. Nucleic Acids Res. 25, 3389-3402. doi: 10.1093/nar/25.17.3389 
Andres, J., Arsene-Ploetze, F., Barbe, V., Brochier-Armanet, C., Cleiss-Arnold, J., Coppee, J. Y., et al. (2013). Life in an arsenic-containing gold mine: genome and physiology of the autotrophic arsenite-oxidizing bacterium Rhizobium sp. NT-26. Genome Biol. Evol. 5, 934-953. doi: 10.1093/gbe/evt061

Anton, A., Weltrowski, A., Haney, C. J., Franke, S., Grass, G., Rensing, C., et al. (2004). Characteristics of zinc transport by two bacterial cation diffusion facilitators from Ralstonia metallidurans CH34 and Escherichia coli. J. Bacteriol. 186, 7499-7507. doi: 10.1128/JB.186.22.7499-7507.2004

Apweiler, R., Bairoch, A., Wu, C. H., Barker, W. C., Boeckmann, B., Ferro, S., et al. (2004). UniProt: the Universal Protein knowledgebase. Nucleic Acids Res. 32, D115-D119. doi: 10.1093/nar/gkh131

Bartosik, D., Bialkowska, A., Baj, J., and Wlodarczyk, M. (1997). Construction of mobilizable cloning vectors derived from pBGS18 and their application for analysis of replicator region of a pTAV202 mini-derivative of Paracoccus versutus pTAV1 plasmid. Acta Microbiol. Pol. 46, 387-392.

Bartosik, D., Szymanik, M., and Wysocka, E. (2001). Identification of the partitioning site within the repABC-type replicon of the composite Paracoccus versutus plasmid pTAV1. J. Bacteriol. 183, 6234-6243. doi: 10.1128/JB.183.21.62346243.2001

Bender, R. A. (2012). Regulation of the histidine utilization (hut) system in bacteria. Microbiol. Mol. Biol. Rev. 76, 565-584. doi: 10.1128/MMBR.00014-12

Birnboim, H. C., and Doly, J. (1979). A rapid alkaline extraction procedure for screening recombinant plasmid DNA. Nucleic Acids Res. 7, 1513-1523. doi: 10.1093/nar/7.6.1513

Bonnin, R. A., Poirel, L., Nordmann, P., Eikmeyer, F. G., Wibberg, D., Puhler, A., et al. (2013). Complete sequence of broad-host-range plasmid pNOR2000 harbouring the metallo-beta-lactamase gene blaVIM-2 from Pseudomonas aeruginosa. J. Antimicrob. Chemother. 68, 1060-1065. doi: 10.1093/jac/ dks526

Carver, T., Berriman, M., Tivey, A., Patel, C., Bohme, U., Barrell, B. G., et al. (2008). Artemis and ACT: viewing, annotating and comparing sequences stored in a relational database. Bioinformatics 24, 2672-2676. doi: 10.1093/bioinformatics/btn529

Caspi, R., Altman, T., Billington, R., Dreher, K., Foerster, H., Fulcher, C. A., et al. (2014). The MetaCyc database of metabolic pathways and enzymes and the BioCyc collection of Pathway/Genome Databases. Nucleic Acids Res. 42, D459-D471. doi: 10.1093/nar/gkt1103

Cevallos, M. A., Cervantes-Rivera, R., and Gutierrez-Rios, R. M. (2008). The repABC plasmid family. Plasmid. 60, 19-37. doi: 10.1016/j.plasmid.2008.03.001

Chen, H. P., Chow, M., Liu, C. C., Lau, A., Liu, J., and Eltis, L. D. (2012). Vanillin catabolism in Rhodococcus jostii RHAl. Appl. Environ. Microbiol. 78, 586-588. doi: 10.1128/AEM.06876-11

Chenna, R., Sugawara, H., Koike, T., Lopez, R., Gibson, T. J., Higgins, D. G., et al. (2003). Multiple sequence alignment with the clustal series of programs. Nucleic Acids Res. 31, 3497-3500. doi: 10.1093/nar/gkg500

Claudel-Renard, C., Chevalet, C., Faraut, T., and Kahn, D. (2003). Enzyme-specific profiles for genome annotation: PRIAM. Nucleic Acids Res. 31, 6633-6639. doi: 10.1093/nar/gkg847

Cole, J. R., Wang, Q., Cardenas, E., Fish, J., Chai, B., Farris, R. J., et al. (2009). The Ribosomal Database Project: improved alignments and new tools for rRNA analysis. Nucleic Acids Res. 37, D141-D145. doi: 10.1093/nar/gkn879

Coleman, S. A., and Minnick, M. F. (2001). Establishing a direct role for the Bartonella bacilliformis invasion-associated locus B (IalB) protein in human erythrocyte parasitism. Infect. Immun. 69, 4373-4381. doi: 10.1128/IAI.69.7.43734381.2001

Debussche, L., Couder, M., Thibaut, D., Cameron, B., Crouzet, J., and Blanche, F. (1992). Assay, purification, and characterization of cobaltochelatase, a unique complex enzyme catalyzing cobalt insertion in hydrogenobyrinic acid a,c-diamide during coenzyme B12 biosynthesis in Pseudomonas denitrificans. J. Bacteriol. 174, 7445-7451.

Dziewit, L., Baj, J., Szuplewska, M., Maj, A., Tabin, M., Czyzkowska, A., et al. (2012). Insights into the transposable mobilome of Paracoccus spp. (Alphaproteobacteria). PLoS ONE 7:e32277. doi: 10.1371/journal.pone.0032277

Dziewit, L., and Bartosik, D. (2014). Plasmids of psychrophilic and psychrotolerant bacteria and their role in adaptation to cold environments. Front. Microbiol. 5:596. doi: 10.3389/fmicb.2014.00596

Dziewit, L., Czarnecki, J., Wibberg, D., Radlinska, M., Mrozek, P., Szymczak, M., et al. (2014a). Architecture and functions of a multipartite genome of the methylotrophic bacterium Paracoccus aminophilus JCM 7686, containing primary and secondary chromids. BMC Genomics $15: 124$. doi: 10.1186/14712164-15-124

Dziewit, L., Oscik, K., Bartosik, D., and Radlinska, M. (2014b). Molecular characterization of a novel temperate Sinorhizobium bacteriophage, LM21, encoding DNA methyltransferase with CcrM-like specificity. J. Virol. 88, 13111-13124. doi: 10.1128/JVI.01875-14

Dziewit, L., Pyzik, A., Matlakowska, R., Baj, J., Szuplewska, M., and Bartosik, D. (2013). Characterization of Halomonas sp. ZM3 isolated from the Zelazny most post-flotation waste reservoir, with a special focus on its mobile DNA. BMC Microbiol. 13:59. doi: 10.1186/1471-2180-13-59

Fath, M. J., and Kolter, R. (1993). ABC transporters: bacterial exporters. Microbiol. Rev. 57, 995-1017.

Gathogo, E. W., Waugh, A. C., Peric, N., Redpath, M. B., and Long, P. F. (2003). Colony PCR amplification of actinomycete DNA. J. Antibiot. 56, 423-424. doi: 10.7164/antibiotics.56.423

Gerdes, S. Y., Kurnasov, O. V., Shatalin, K., Polanuyer, B., Sloutsky, R., Vonstein, V., et al. (2006). Comparative genomics of NAD biosynthesis in cyanobacteria. J. Bacteriol. 188, 3012-3023. doi: 10.1128/JB.188.8.3012-3023.2006

Heuer, H., and Smalla, K. (2012). Plasmids foster diversification and adaptation of bacterial populations in soil. FEMS Microbiol. Rev. 36, 1083-1104. doi: 10.1111/j.1574-6976.2012.00337.x

Hoiczyk, E., Roggenkamp, A., Reichenbecher, M., Lupas, A., and Heesemann, J. (2000). Structure and sequence analysis of Yersinia YadA and Moraxella UspAs reveal a novel class of adhesins. EMBO J. 19, 5989-5999. doi: 10.1093/emboj/19.22.5989

Huang, T. W., Wang, J. T., Lauderdale, T. L., Liao, T. L., Lai, J. F., Tan, M. C., et al. (2013). Complete sequences of two plasmids in a blaNDM-1-positive Klebsiella oxytoca isolate from Taiwan. Antimicrob. Agents Chemother. 57, 4072-4076. doi: 10.1128/AAC.02266-12

Kholodii, G., Yurieva, O., Mindlin, S., Gorlenko, Z., Rybochkin, V., and Nikiforov, V. (2000). Tn5044, a novel Tn3 family transposon coding for temperaturesensitive mercury resistance. Res. Microbiol. 151, 291-302. doi: 10.1016/S09232508(00)00149-2

Klockgether, J., Reva, O., Larbig, K., and Tummler, B. (2004). Sequence analysis of the mobile genome island pKLC102 of Pseudomonas aeruginosa C. J. Bacteriol. 186, 518-534. doi: 10.1128/JB.186.2.518-534.2004

Lane, D. J. (1991). "16S/23S rRNA sequencing," in Nucleic Acid Techniques in Bacterial Systematics, eds E. Stackebrandt and M. Goodfellow. (New York, NY: Wiley), 115-175.

Larson, H. (1986). Halophilic and halotolerant microorganisms-an overview and historical perspective. FEMS Microbiol. Rev. 39, 3-7. doi: 10.1111/j.15746968.1986.tb01835.x

Lowe, T. M., and Eddy, S. R. (1997). tRNAscan-SE: a program for improved detection of transfer RNA genes in genomic sequence. Nucleic Acids Res. 25, 955-964. doi: $10.1093 /$ nar/25.5.0955

Maj, A., Dziewit, L., Czarnecki, J., Wlodarczyk, M., Baj, J., Skrzypczyk, G., et al. (2013). Plasmids of carotenoid-producing Paracoccus spp. (Alphaproteobacteria) - structure, diversity and evolution. PLoS ONE 8:e80258. doi: 10.1371/journal.pone.0080258

Martin, P. R., Shea, R. J., and Mulks, M. H. (2001). Identification of a plasmidencoded gene from Haemophilus ducreyi which confers NAD independence. J. Bacteriol. 183, 1168-1174. doi: 10.1128/JB.183.4.1168-1174.2001

Masai, E., Yamamoto, Y., Inoue, T., Takamura, K., Hara, H., Kasai, D., et al. (2007). Characterization of ligV essential for catabolism of vanillin by Sphingomonas paucimobilis SYK-6. Biosci. Biotechnol. Biochem. 71, 2487-2492. doi: $10.1271 /$ bbb.70267

Matlakowska, R., Narkiewicz, W., and Sklodowska, A. (2010). Biotransformation of organic-rich copper-bearing black shale by indigenous microorganisms isolated from lubin copper mine (Poland). Environ. Sci. Technol. 44, 2433-2440. doi: $10.1021 /$ es $903298 \mathrm{t}$

Matlakowska, R., and Sklodowska, A. (2009). The culturable bacteria isolated from organic-rich black shale potentially useful in biometallurgical procedures. J. Appl. Microbiol. 107, 858-866. doi: 10.1111/j.1365-2672.2009.04261.x

Matlakowska, R., and Sklodowska, A. (2011). Biodegradation of Kupferschiefer black shale organic matter (Fore-Sudetic Monocline, Poland) by indigenous microorganisms. Chemosphere 83, 1255-1261. doi: 10.1016/j.chemosphere.2011.03.003

Matlakowska, R., Sklodowska, A., and Nejbert, K. (2012). Bioweathering of kupferschiefer black shale (Fore-Sudetic Monocline, SW Poland) by indigenous 
bacteria: implication for dissolution and precipitation of minerals in deep underground mine. FEMS Microbiol. Ecol. 81, 99-110. doi: 10.1111/j.15746941.2012.01326.x

Meyer, F., Goesmann, A., Mchardy, A. C., Bartels, D., Bekel, T., Clausen, J., et al. (2003). GenDB - an open source genome annotation system for prokaryote genomes. Nucleic Acids Res. 31, 2187-2195. doi: 10.1093/nar/gkg312

Ng, S. P., Davis, B., Palombo, E. A., and Bhave, M. (2009). A Tn5051-like mercontaining transposon identified in a heavy metal tolerant strain Achromobacter sp. AO22. BMC Res. Notes 2:38. doi: 10.1186/1756-0500-2-38

Nieto, J. J., Ventosa, A., and Ruiz-Berraquero, F. (1987). Susceptibility of halobacteria to heavy metals. Appl. Environ. Microbiol. 53, 1199-1202.

Nojiri, H. (2013). Impact of catabolic plasmids on host cell physiology. Curr. Opin. Biotechnol. 24, 423-430. doi: 10.1016/j.copbio.2012.09.014

Oszczepalski, S. (1999). Origin of the Kupferschiefer polymetallic mineralization in Poland. Mineral. Deposita 34, 599-613. doi: 10.1007/s001260050222

Parkhill, J., Dougan, G., James, K. D., Thomson, N. R., Pickard, D., Wain, J., et al. (2001). Complete genome sequence of a multiple drug resistant Salmonella enterica serovar Typhi CT18. Nature 413, 848-852. doi: 10.1038/35101607

Preston, K. E., Hitchcock, S. A., Aziz, A. Y., and Tine, J. A. (2014). The complete nucleotide sequence of the multi-drug resistance-encoding IncL/M plasmid pACM1. Plasmid 76, 54-65. doi: 10.1016/j.plasmid.2014.08.005

Rahube, T. O., Viana, L. S., Koraimann, G., and Yost, C. K. (2014). Characterization and comparative analysis of antibiotic resistance plasmids isolated from a wastewater treatment plant. Front. Microbiol. 5:558. doi: 10.3389/fmicb.2014.00558

Rajpert, L., Sklodowska, A., and Matlakowska, R. (2013). Biotransformation of copper from Kupferschiefer black shale (Fore-Sudetic Monocline, Poland) by yeast Rhodotorula mucilaginosa LM9. Chemosphere 91, 1257-1265. doi: 10.1016/j.chemosphere.2013.02.022

Sambrook, J., and Russell, D. W. (2001). Molecular Cloning: A Laboratory Manual. New York, NY: Cold Spring Harbor Laboratory Press.

Santamaria, R. I., Bustos, P., Sepulveda-Robles, O., Lozano, L., Rodriguez, C., Fernandez, J. L., et al. (2014). Narrow-host-range bacteriophages that infect Rhizobium etli associate with distinct genomic types. Appl. Environ. Microbiol. 80, 446-454. doi: 10.1128/AEM.02256-13

Schwyn, B., and Neilands, J. B. (1987). Universal chemical assay for the detection and determination of siderophores. Anal. Biochem. 160, 47-56. doi: 10.1016/0003-2697(87)90612-9

Silver, S. (1996). Bacterial resistances to toxic metal ions - a review. Gene 179, 9-19. doi: 10.1016/S0378-1119(96)00323-X

Silver, S., and Phung Le, T. (2005a). A bacterial view of the periodic table: genes and proteins for toxic inorganic ions. J. Ind. Microbiol. Biotechnol. 32, 587-605. doi: $10.1007 /$ s10295-005-0019-6

Silver, S., and Phung Le, T. (2005b). Genes and enzymes involved in bacterial oxidation and reduction of inorganic arsenic. Appl. Environ. Microbiol. 71, 599-608. doi: 10.1128/AEM.71.2.599-608.2005

Sklodowska, A., Matlakowska, R., and Bal, K. (2005). Extracellular polymer produced in the presence of copper minerals during bioleaching. Geomicrobiol. J. 22, 1-9. doi: 10.1080/01490450590922596

Slonczewski, J. L., Fujisawa, M., Dopson, M., and Krulwich, T. A. (2009). Cytoplasmic $\mathrm{pH}$ measurement and homeostasis in bacteria and archaea. Adv. Microb. Physiol. 55, 317. doi: 10.1016/S0065-2911(09) 05501-5

Sobecky, P. A., and Coombs, J. M. (2009). Horizontal gene transfer in metal and radionuclide contaminated soils. Methods Mol. Biol. 532, 455-472. doi: 10.1007/978-1-60327-853-9_26

Speczik, S. (1994). Kupferschiefer mineralization in the light of organic geochemistry and coal petrology studies. Geol. Q. 38, 639-650.

Speczik, S. (1995). The Kupferschiefer mineralization of Central Europe: new aspects and major areas of future research. Ore. Geol. Rev. 9, 411-426. doi: 10.1016/0169-1368(94)00022-G

Stein, D. C., Chien, R., and Seifert, H. S. (1992). Construction of a Neisseria gonorrhoeae MS11 derivative deficient in NgoMI restriction and modification. J. Bacteriol. 174, 4899-4906.

Szuplewska, M., and Bartosik, D. (2009). Identification of a mosaic transposable element of Paracoccus marcusii composed of insertion sequence ISPmar4 (ISAs1 family) and an IS1247a-driven transposable module (TMo). FEMS Microbiol. Lett. 292, 216-221. doi: 10.1111/j.1574-6968.2009.01495.x

Szuplewska, M., Ludwiczak, M., Lyzwa, K., Czarnecki, J., and Bartosik, D. (2014). Mobility and generation of mosaic non-autonomous transposons by $\operatorname{Tn} 3-$ derived inverted-repeat miniature elements (TIMEs). PLoS ONE 9:e105010. doi: 10.1371/journal.pone.0105010

Tamminen, M., Virta, M., Fani, R., and Fondi, M. (2012). Large-scale analysis of plasmid relationships through gene-sharing networks. Mol. Biol. Evol. 29, 1225-1240. doi: 10.1093/molbev/msr292

Tamura, K., Stecher, G., Peterson, D., Filipski, A., and Kumar, S. (2013). MEGA6: molecular evolutionary genetics analysis version 6.0. Mol. Biol. Evol. 30, 2725-2729. doi: 10.1093/molbev/mst197

Wheatcroft, R., Mcrae, G. D., and Miller, R. W. (1990). Changes in the Rhizobium meliloti genome and the ability to detect supercoiled plasmids during bacteroid development. Mol. Plant Microbe. Inter. 3, 9-17. doi: 10.1094/ MPMI-3-009

Conflict of Interest Statement: The authors declare that the research was conducted in the absence of any commercial or financial relationships that could be construed as a potential conflict of interest.

Received: 07 January 2015; accepted: 09 February 2015; published online: 03 March 2015.

Citation: Dziewit L, Pyzik A, Szuplewska M, Matlakowska R, Mielnicki S, Wibberg D, Schlüter A, Pühler A and Bartosik D (2015) Diversity and role of plasmids in adaptation of bacteria inhabiting the Lubin copper mine in Poland, an environment rich in heavy metals. Front. Microbiol. 6:152. doi: 10.3389/fmicb.2015.00152

This article was submitted to Terrestrial Microbiology, a section of the journal Frontiers in Microbiology.

Copyright (C) 2015 Dziewit, Pyzik, Szuplewska, Matlakowska, Mielnicki, Wibberg, Schlüter, Pühler and Bartosik. This is an open-access article distributed under the terms of the Creative Commons Attribution License (CC BY). The use, distribution or reproduction in other forums is permitted, provided the original author(s) or licensor are credited and that the original publication in this journal is cited, in accordance with accepted academic practice. No use, distribution or reproduction is permitted which does not comply with these terms. 